\title{
Profile of cystic fibrosis in two reference centers in southern Brazil
}

\author{
Laís Cristina Rizzo ${ }^{1}$, Gilberto Bueno Fischer ${ }^{2}$, Paulo José Cauduro Maróstica ${ }^{3}$, Helena Teresinha Mocelin ${ }^{4}$ \\ ${ }^{1}$ Master's degree in Pulmonology at the Federal University of Rio Grande do Sul (UFRGS), Porto Alegre, RS, Brazil \\ ${ }^{2} \mathrm{PhD}$ in Pulmonology - Lecturer at the Federal University of Health Sciences of Porto Alegre (UFCSPA), Porto Alegre, RS, Brazil \\ 3Postdoctor - Assistant Professor at Pontifícia Universidade Católica of Rio Grande do Sul (PUCRS), Porto Alegre, RS, Brazil \\ ${ }^{4} \mathrm{PhD}$ in Pulmonology at the UFRGS, Porto Alegre, RS, Brazil
}

\begin{abstract}
SUMMARY
Study conducted at Holy House Hospital Complex in Porto Alegre, RS, Brazil

Article received: 3/12/2014 Accepted for publication: $8 / 15 / 2014$

*Correspondence: Address: Rua Professor Anes Dias, 285, Centro

Porto Alegre, RS - Brazil Postal code: 90020-090 laisrizzo.Ir@gmail.com

http://dx.doi.org/10.1590/1806-9282.61.02.150

Objective: to compare the characteristics of cystic fibrosis patients treated in two reference centers in southern Brazil in order to observe trends in the treatment and clinical outcomes that may produce changes in clinical conduct.

Methods: cross-sectional, retrospective study with 83 patients diagnosed with cystic fibrosis, aged one month to eighteen years. The variables analyzed were obtained through review of medical records, including: demographic and clinical characteristics, socioeconomic status, pulmonary function test, bacterial colonization profile, medication and physiotherapy.

Results: between the two centers there was significant difference in the variables, including admissions in the previous year $(\mathrm{p}<0.001)$, lifetime hospital admissions $(\mathrm{p}<0.001)$, use of Dornase alpha $(\mathrm{p}=0.003)$ and inhaled antibiotic therapy $(\mathrm{p}=0.006)$, which were higher at the Santo Antônio Children's Hospital (HCSA), while age at first colonization with Staphylococcus aureus $(\mathrm{p}=0.008)$, maternal age $(\mathrm{p}=0.030)$, clinical score $(\mathrm{p}=0.001)$, socioeconomic score $(\mathrm{p}=0.021)$ and use of hypertonic saline $(\mathrm{p}<0.001)$ were lower at HCSA compared to São Lucas Hospital (HSL).

Conclusion: the study centers seem to receive a different population of patients, both in socioeconomic terms, as well as disease severity, which interferes with the choice of medication treatment. At the HCSA, preventive actions against infection due to the high incidence of Burkholderia cepacia Complex and careful research into early lung changes will be encouraged.
\end{abstract} Conflict of interest: none
Keywords: cystic fibrosis, pediatrics, chronic disease.

\section{INTRODUCTION}

Cystic fibrosis $(\mathrm{CF})$ is a hereditary genetic disorder, most common in Caucasians, manifested in the majority of individuals in the early years of life. ${ }^{1}$ In Brazil, the prevalence is estimated at 1:10,000 live births, although there are variations in the frequency of mutations in different regions. ${ }^{2}$ In southern state of Rio Grande do Sul (RS), it has been estimated that the incidence is closer to that seen in white Central European populations. However, through the preliminary results of neonatal screening in $\mathrm{RS}$, it became clear that this incidence is lower, between 1:5000-1:8000 live births.

Changes in the function of the exocrine glands compromise the functioning of virtually every organ and system, and may lead to a fatal outcome. ${ }^{3,4}$ Thus, knowl- edge of the clinical course and treatment of these patients, monitored in several Brazilian health centers, can be extremely important in identifying poor prognostic markers.

Treatment is complex, involving the continuous use of medication, physiotherapy and nutritional supplementation. From the 1930s, there has been a significant increase in patient survival attributed to improved antimicrobial and nutritional treatments. ${ }^{5}$ However, the differences among the patients treated at different centers can contribute to different clinical results and therapeutic choices, because there is no universal consensus on the management of such patients. ${ }^{6}$

Therefore, the planning of epidemiological studies to understand the Brazilian population of CF patients is 
fundamental for uniform and effective national action in the intervention and diagnosis of this condition. ${ }^{6}$

Considering that, in Brazil, the state of Rio Grande do Sul potentially has the largest population of patients and carriers of the CF gene, ${ }^{7}$ this study aims to compare the profile of patients found in two reference centers in the state's capital, Porto Alegre, in order to observe treatment trends and clinical outcomes that will produce possible changes in medical conduct.

\section{Methodology}

A descriptive, retrospective and cross-sectional study was conducted, including patients with cystic fibrosis, monitored at the outpatient clinics of the Santo Antonio Children's Hospital (HCSA) and São Lucas Hospital of the Pontifical Catholic University (HSL-PUCRS), in Porto Alegre. The HCSA is linked to the Federal University of Health Sciences of Porto Alegre and the HSL-PUCRS receives students of the Pontifical Catholic University of Rio Grande do Sul, which is a private institution. Despite the HCSA having existed for a longer period of time, the cystic fibrosis service at the HSL-PUCRS is older. However, both hospitals offer public and private services, being the HCSA more likely to receive a greater number of patients under the national public health system (Unified Health System, or SUS). Both institutions are located in central areas of the city and receive patients from throughout the state, in addition to receiving patients from other parts of the country.

We selected all patients aged from one month to 18 years who had at least one visit recorded in medical records in 2010, and had a diagnosis confirmed by a strongly suggestive clinical history, which is defined as chronic obstructive pulmonary disease; persistent pulmonary colonization mainly by Pseudomonas aeruginosa; meconium ileus; pancreatic insufficiency with impaired development; family history of the disease, and at least two sweat tests with an amount of chlorine above $60 \mathrm{mEq} / \mathrm{L}$, or the identification of two typical mutations of the disease ( $\triangle \mathrm{F} 508$ and/or other). The study excluded patients who had incomplete data from the medical records, such as the number of hospitalizations, current bacterial colonization and clinical characteristics.

The information collected from the patients' medical records included: age, age at diagnosis, age at onset of symptoms, age of parents, color, number of exacerbations in 2010, number of hospital admissions in 2010, number of lifetime admissions, pulmonary impairment, digestive impairment, meconium ileus, anthropometric data, bacterial colonization in 2010, the first colonization by Staphylococcus aureus (SA), first colonization by Psendomo- nas aeruginosa (PSA), first colonization by Burkbolderia cepacia complex (BCC), Shwachman-Kulczycki score (SK), socioeconomic score (CCEB), drug treatment, number of prescriptions for daily physiotherapy, spirometry variables, and distance covered in the six minute walk test (6MWT).

\section{Statistical analysis}

The assessment of the distribution of the variables was conducted using Kolmogorov-Smirnov test. Continuous variables were expressed as the mean and standard deviation; variables with asymmetric distribution were expressed through the median and interquartile range ( $\mathrm{p} 25-$ p75), while categorical variables were described as absolute and relative frequencies. The Student's $t$ test was used for comparisons for the parametric variables. For comparisons with non-parametric distribution, the Wilcoxon signed-rank test was used. For the analysis of proportions, the chi-square test was used, with adjusted residuals tested using Fisher exact test. Significance was considered when $\mathrm{p} \leq 5 \%$. The study was approved by the Research Ethics Committee of the Holy House Hospital Complex of Porto Alegre and the HSL-PUCRS.

\section{ResULtS}

86 patients met the inclusion criteria for this study: 25 from the HCSA and 61 from the HSL-PUCRS. Three patients from the HSL-PUCRS were excluded for presenting insufficient data in the medical records, regarding 2010. The sample totaled 83 patients. The clinical characteristics of the patients from both centers can be found in Table 1 . The differences found related to the number of admissions in 2010, which was higher at the HCSA, the number of hospitalizations in life, also higher in HCSA, socioeconomic classification (CCEB), in which patients from the HCSA had lower scores, and disease severity (Shwachman-Kulczycki [S-K] score), according to which patients from the HCSA showed increased severity.

In relation to CF diagnostic aspects, the dosage of immunoreactive trypsinogen (IRT) was undertaken in only four patients from the HCSA group and seven from the HSL-PUCRS, and in all patients the values were higher than $70 \mathrm{ng} / \mathrm{mL}$. The averages for sodium and chlorine in sweat were altered in both centers: chlorine $75.94 \pm$ 26.78 and $72.76 \pm 20.22$, HCSA and HSL-PUCRS, respectively. Research was carried out for CF gene mutations in nine patients from the HCSA, with the $\Delta$ F508 being found in 8 patients. The same was done in 20 patients from the HSL-PUCRS, with $\Delta$ F508 mutation identified in at least one allele in 13 patients. 
TABLE 1 Comparison of HCSA and HSL-PUCRS patient characteristics.

\begin{tabular}{llll} 
Variables & HCSA (25) & PUCRS (58) & P value \\
\hline Male & $44 \%(11)$ & $60.34 \%(35)$ & 0.073 \\
\hline Age (months) & $96(50.5-126)$ & $132(72-156)$ & 0.085 \\
\hline White & $88 \%(22)$ & $91.38(53)$ & 0.134 \\
\hline Age at onset of symptoms (months) & $3(0.25-13.5)$ & $2(0-28.5)$ & 0.886 \\
\hline Time without monitor. diag. (months) & $11.5(1-42)$ & $1(0-30.5)$ & 0.073 \\
\hline Age upon diagnosis (months) & $14(2.5-66)$ & $36(3-96)$ & 0.446 \\
\hline Exacerbations & $1(1-2)$ & $1(0-2)$ & 0.486 \\
\hline Admissions 2010 & $1(1-1)$ & $0(0-0.5)$ & $<0.001^{*}$ \\
\hline Life admissions & $8(1.25-20)$ & $1(0-4)$ & $<0.001^{*}$ \\
\hline Pulmonary impair. & $92 \%(23)$ & $75.86 \%(44)$ & 0.087 \\
\hline Digestive impair. & $96 \%(24)$ & $87.93 \%(51)$ & 0.253 \\
\hline Meconium ileus & $16 \%(4)$ & $8.62 \%(5)$ & 0.321 \\
\hline Eutrophic 2010 & $78.57 \%$ & $81.13 \%$ & 0.232 \\
\hline Eutrophic upon diagnosis & $66.66 \%$ & $74.28 \%$ & 0.289 \\
\hline S-K & $80.21 \pm 10.47$ & $86.85 \pm 7.71$ & $0.001^{*}$ \\
\hline CCEB & $21.18 \pm 5.86$ & $25.45 \pm 7.39$ & $0.021^{*}$ \\
\hline
\end{tabular}

The data are presented as mean \pm standard deviation, median (interquartile interval) or \% (absolute $n$ ). diag. - diagnosis, Time without monitor. diag. - monitoring time before diagnosis, Impair. - impairment, S-K - Schwachman-Kulczyki, CCEB Score - Economic Classification Criteria, Brazil. Student's $t$ test, Mann-Whitney U test, Chi Square, significance ${ }^{*} \mathrm{p} \leq 0.05$.

Only one patient belonging to the HSL-PUCRS center had a diagnosis of diabetes mellitus. Consanguinity between parents was identified in two patients from the HCSA and in one from the HSL-PUCRS. In both centers, the median of families with CF was zero, and the maximum of relatives with $\mathrm{CF}$ in the same family was two. The average age of the mothers was $34.52 \pm 8.76$ years at the HCSA and $40.38 \pm 7.36$ years at the HSL-PUCRS, a statistically significant difference $(\mathrm{p}=0.030)$. In comparing the age of the fathers, there was no statistically significant difference ( $\mathrm{p}=0.055)$, with an average of $38.27 \pm 7.88$ at the HCSA and $44.09 \pm 8.27$ at the HSLPUCRS.

There was a difference in the onset of colonization by Staphylococcus aureus (SA) in patients at the centers studied, which was 13 (2-84) months at the HCSA and 66 (1$170)$ months at the HSL-PUCRS $(p=0.008)$. There was also difference in bacterial colonization in 2010, so that the patients from the HCSA were significantly more affected by Burkholderia cepacea ( $28 \%$ of patients). The HSLPUCRS center presented a higher percentage of patients without bacterial colonization at $39.65 \%(\mathrm{p}=0.031)$. Pulmonary function, assessed using spirometry, showed a statistically significant difference between the centers, only in terms of forced expiratory flow between 25 and $75 \%$ of the forced vital capacity curve $\left(\mathrm{FEF}_{25-75}\right)$ (Table 2$)$.
TABLE 2 Comparison between the pulmonary function parameters at the 2 centers.

\begin{tabular}{llll} 
Variables & $\begin{array}{l}\text { HCSA } \\
(\mathbf{2 0})\end{array}$ & $\begin{array}{l}\text { PUCRS } \\
\mathbf{( 4 7 )}\end{array}$ & $\begin{array}{l}\mathbf{P} \\
\text { value }\end{array}$ \\
\hline $\begin{array}{l}\text { FVC } \\
\text { (\% of predicted) }\end{array}$ & $104.67 \pm 14.68$ & $106.39 \pm 24.41$ & 0.457 \\
\hline $\begin{array}{l}\mathrm{FEV} \\
\text { (\% of predicted) }\end{array}$ & $99 \pm 20.42$ & $94.91 \pm 24.6$ & 0.658 \\
\hline $\begin{array}{l}\mathrm{FEV}_{1} / \mathrm{FVC} \\
\text { (absolute } \mathrm{n})\end{array}$ & $0.82 \pm 0.11$ & $0.83 \pm 0.09$ & 0.364 \\
\hline $\begin{array}{l}\mathrm{FEF}_{25-75} \\
\text { (\% of predicted) }\end{array}$ & $75.15 \pm 32.23$ & $81.10 \pm 35.41$ & $0.021^{*}$ \\
\hline
\end{tabular}

The data are presented as the mean \pm standard deviation. FVC - Forced Vital Capacity, FEV forced expiratory volume in the first second, $\mathrm{FEF}_{25-75^{-}}$. Forced expiratory flow between 25 and $75 \%$ of the Forced Vital Capacity curve.

Reference of the predicted value, Pereira et al, 2002. Student's t-test, significant ${ }^{*} \mathrm{p} \leq 0.05$.

A statistically significant difference was found between the percentages of predicted value covered in the six minute walk test. Twelve patients from the HCSA and 29 from the HSL-PUCRS underwent the six minute walk test with a mean of $86.54 \pm 15.05$ and $97.08 \pm 8.33(\mathrm{p}=0.008)$ meters, respectively. Table 3 shows the choice of treatment used at each center. The use of enzymes was the only variable that showed no significant difference between the centers. 
TABLE 3 Comparison between treatment choices at each center.

\begin{tabular}{llll} 
Variables & HCSA & PUCRS & P value \\
\hline Use of dornase $\alpha$ & $52 \%(13)$ & $25.86 \%(15)$ & $0.003^{*}$ \\
\hline Use of inhaled antib. & $68 \%(17)$ & $32.76 \%(19)$ & $0.006^{*}$ \\
\hline Use of HSS & $0 \%$ & $46.55 \%(27)$ & $<0.001^{*}$ \\
\hline Use of enzymes & $96 \%(24)$ & $83.64 \%(46 / 55)$ & 0.132 \\
\hline Daily physiotherapy & $2.16 \pm 0.9$ & $1.18 \pm 0.76$ & $<0.001^{*}$ \\
\hline
\end{tabular}

The data are presented in \% (n) or mean \pm standard deviation. Antib. - antibiotics, HSS - Hypertonic Saline Solution. Chi square, Fisher's exact test and Student's t-test, significant ${ }^{*} \mathrm{p}<0.05$.

Regarding home treatment, there was a significant difference as to the person administering the enzymes $(\mathrm{p}=0.001)$ or conducting the physiotherapy $(\mathrm{p}=0.004)$. At the HCSA, in $64 \%$ of patients the mother administers the enzymes, while at the HSL-PUCRS the percentage is $25 \%$. Enzyme treatment is self-administered in $40.62 \%$ of HSLPUCRS patients and in $25 \%$ at the HCSA. At the HCSA, physiotherapy is conducted by the mother in $52 \%$ of patients and both parents in $26 \%$, while at the HSL-PUCRS, in 21.7 and $46.88 \%$, respectively. A difference was not found in relation to the person taking patients to appointments $(\mathrm{p}=0.133)$.

\section{Discussion}

Through this study, it was possible to characterize a portion of pediatric CF patients in Rio Grande do Sul. A study by another reference center in Porto Alegre gave a description that included 116 patients and found a mean age of 10.5 years with a predominance of males and median diagnosis at eight months. The prevalent bacterial culture was Staphylococcus aureus (88.6\%), followed by Psendomonas aeruginosa (59.04\%), Burkholderia cepacea (22.9\%) and negative cultures $(29.2 \%){ }^{8}$ These data corroborate a more complete analysis of the CF patient population in Rio Grande do Sul, showing similar colonization to the HCSA, despite the rate of negative cultures closer to the HSLPUCRS.

This study draws attention to the late diagnosis at 14(2.5-66) months in the case of HCSA and 36(3-96) months at the HSL-PUCRS. This can be explained by the fact that, in RS, the TNN program for CF offered by the SUS health system began in 2012. However, the data collected by the Brazilian Cystic Fibrosis Registry (RBFC) until 2010 also demonstrated a late diagnosis, 19.05(1288.2) months. ${ }^{9}$ A study by Monestrol et al. ${ }^{10}$ showed that patients diagnosed after 24 months of age have higher lung, liver and nutritional morbidity. ${ }^{10}$

In the present study, digestive involvement was present in $96 \%$ of HCSA patients and $87.93 \%$ of the HSL-PUCRS pa- tients, with no statistically significant difference. Enzyme replacement therapy also showed no difference between the two centers. This finding is similar to European data, where the prevalence of digestive commitment reaches $90 \% .{ }^{4}$

Since 1949, it has been known that, in general, SA is the first pathogen to infect patients with $\mathrm{CF}$, which was also observed in this study. The percentage of patients colonized with this bacterium in 2010 was $12 \%$ at the HCSA and $20.7 \%$ at the HSL-PUCRS. According to the RBFC, 57.7\% of 1562 patients registered with bacterial cultures up to 2010 are colonized with SA. PSA had a prevalence of $44 \%$ at the HCSA and $25.86 \%$ at the HSL-PUCRS. This prevalence was lower than that found in a study in another center in the same city as the centers analyzed, where prevalence for this bacteria was $51 \%{ }^{8}$ According to the Cystic Fibrosis Foundation Registry, the PSA colonization rate before age 18 is $39 \%$, but as PSA is considered the most common bacteria in these patients, it is believed that from the age of $18,75 \%$ patients are infected by it. ${ }^{4}$ In a study conducted at another center in Brazil, Li et al. ${ }^{5}$ found an average age of 12 months for the first colonization by PSA and in this study we noticed a later colonization of 37 (13 to 56.5) at the HCSA and 90 (21-128) at the HSL-PUCRS. ${ }^{5}$ Speert et al. ${ }^{12}$ observed that most patients retain their own unique strain and very close contact is required for PSA to spread among the patients. They also concluded that the incidence of cross contamination between unrelated CF patients is very low. ${ }^{11,12}$

The HCSA patients had a high prevalence of BCC (28\%), which should be given urgent attention as according to Mehta et al., ${ }^{13}$ BCC is associated with a worse prognosis, including a rapid decline in clinical status and increased risk of mortality. ${ }^{13}$ This bacterium is present in $10.4 \%$ of Brazilian CF patients with bacterial colonization. The high prevalence of BCC at the HCSA can be explained by this being a recent center with routines being implemented and more clinically compromised patients. Although the HSLPUCRS center presented a much lower percentage of BCC colonization (5.17\%), the Clinic Hospital of Porto Alegre center, which is the first center deployed in RS, presented a similar percentage $(22.9 \%)$ to the HCSA. ${ }^{8}$

The forced expiratory flow between 25 and $75 \%$ of the $\mathrm{FVC}\left(\mathrm{FEF}_{25-75}\right)$ was the only lung function parameter with significant difference between the two centers, and was lower in HCSA patients. The progression of the disease in $\mathrm{CF}$ is assessed by the assessment of pulmonary function using forced vital capacity (FVC), forced expiratory volume in one second $\left(\mathrm{FEV}_{1}\right)$ and $\mathrm{FEF}_{25-75}$. It is also known that the $\mathrm{FEF}_{25-75}$ is the lung function that changes the earliest when lung function becomes impaired, ${ }^{14}$ indicating that despite the patients in this study having presented "normal" aver- 
age spirometry values, the patients at HCSA may develop decreased lung function earlier. This result reinforces the trend of greater severity in HCSA patients, perceived through lower SK scores and the higher incidence of lifetime hospital admission and during the year 2010.

Comparing drug therapy used in the two centers, we can see a greater use of dornase $\alpha$ at the HCSA, while the HSL-PUCRS center uses HSS more often. A 17 year cohort study conducted in London, showed that Dornase $\alpha$ was significantly associated with reduced risk of death. ${ }^{15}$ Konstan et al. ${ }^{17}$ conducted a study of CF patients aged 8-38 years, and concluded that the use of Dornase $\alpha$ for a period of two years was associated with a lower decline in $\mathrm{FEV}_{1}{ }^{16}$ The difference found between the two centers studied can also be seen in the six minute walk test, in which the HCSA patients had lower values in the percentage predicted for the test. This reduction in exercise capacity is associated with a decline in lung function and lower survival. ${ }^{17}$

The increased use of inhaled antibiotics at the HCSA could be influenced by the greater number of patients with BCC, for which inhaled treatment is currently indicated.

Three other studies have evaluated the safety, tolerability and adherence of HSS. HSS was well tolerated and safe in children from 12 months to 18 years of age, and coughing was the most common symptom after administration. Patients who had less tolerance were those who had worse lung function. ${ }^{18,19}$ However, a study published by Laube et al. ${ }^{20}$ has shown that children with CF and normal lung function did not show better bronchial hygiene after inhalation of HSS and that perhaps there is a difference in results between gender. ${ }^{20}$

In the comparison between the centers, a significant difference was found in the prescription of daily physiotherapy with a mean of $2.16 \pm 0.9$ at the HCSA and 1.18 \pm 0.76 at the HSL-PUCRS, which can be justified by the tendency towards more serious cases at the HCSA which, therefore, may require a greater number of physiotherapy sessions. Traditionally, a regime of two daily physiotherapy sessions has been defended at the time of confirmation of the CF diagnosis. This argument can be considered as some studies suggest that infection and inflammation are present in the lungs of some babies from a very early stage in the disease process, long before the manifestation of respiratory signs and symptoms. ${ }^{21}$

As for family care, this study showed that there were differences in home care, with the mother having more responsibility for treatment at the HCSA, while at the HSLPUCRS center parents sought to share this responsibility. As $\mathrm{CF}$ affects various bodily systems, it requires complex care and continuous attention to promote a stable clinical status of the patient, therefore, involvement of the family is indispensable, in the most varied ways. In the study by Furtado et al., ${ }^{22}$ mothers, as in the case of the HCSA, ended up centralizing responsibility for the child's treatment at home. Mothers often abstain from other activities outside the home in order to better serve the needs of children. ${ }^{22}$

There was a significant difference between socioeconomic scores (CCEB) in the centers studied, with a lower score at the HCSA. This score includes parental age, education level and income, allowing an insight into the reality of these families, as well as including important variables for finding risk factors for childhood respiratory diseases. ${ }^{23,24}$ According to a study in a CF center in São Paulo, most parents of children/adolescents with CF were aged between 31 and 40 years and had not completed elementary school, which compromises family income. ${ }^{24}$ These families earned between one and to minimum salaries, which is in accordance with the findings at the HCSA.

The limitations of this study include its dependency on data contained in the medical records, the limitations related to retrospective studies and the lack of analysis of genetic mutations, which could indicate clinical aspects, and their associations with a worse or better prognosis. Nevertheless, $55.5 \%$ of the CF patients monitored in Brazil do not have a genetic test. Moreover, it is important to state that this research analyzes data from two services with different routines, including microbiology, spirometry, and more. Another limitation is the great variability of some of the findings, such as age, age at onset of symptoms, monitoring time before the diagnosis, age at diagnosis, lifetime hospital admissions, as well as the inability to collect some variables in the entire sample, such as results for six minute walk test and spirometry.

Therefore, the centers studied seem to receive different populations of patients. The HCSA patients have worse general health, with a higher number of hospital admissions in 2010 and also throughout life, more severe clinical scores, early colonization by SA and a disadvantaged socioeconomic profile. This differentiated patient profile interferes with the choice of treatment, demonstrating differences in terms of drug therapy and the number of physiotherapy treatments.

The means of the lung function variables did not present values lower than those predicted at both centers, although $\mathrm{FEF}_{25-75}$ was lower in HCSA patients. This result is a strong suggestion of earlier lung damage in patients at this center, because there are studies demonstrating that, even in children diagnosed via neonatal screening, there are already indications of pulmonary disease. ${ }^{25}$

The HCSA also presented a higher BCC colonization rate, which could indicate greater severity among HCSA 
patients. A study could, therefore, be suggested to analyze the high incidence of Burkholderia cepacea complex at the HCSA, including genotyping to attempt to stimulate preventive actions against infection.

\section{Conclusion}

A follow-up of this study is important with perhaps the inclusion of more variables. We could then monitor CF patients over the years, observing how they respond to treatment in an attempt to adapt and improve care.

\section{Resumo}

Perfil da fibrose cística em dois centros de referência do sul do Brasil.

Objetivo: comparar o perfil de pacientes com fibrose cística em dois centros de referência do Sul do Brasil - Hospital da Criança Santo Antônio (HCSA) e Hospital São Lucas para observar tendências no tratamento e desfechos clínicos que produzirão possíveis modificações de conduta.

Métodos: estudo transversal, retrospectivo, com 83 pacientes com fibrose cística, de idade entre 1 mês e 18 anos. As variáveis analisadas, obtidas por meio da revisão de prontuários, foram: características demográficas, clínicas e socioeconômicas, teste de função pulmonar, perfil de infecção, tratamento medicamentoso e fisioterápico.

Resultados: entre os dois centros, houve diferença estatisticamente significativa nas variáveis a seguir: internações no último ano $(\mathrm{p}<0,001)$, internações na vida $(\mathrm{p}<0,001)$, uso de dornase $\alpha(\mathrm{p}=0,003)$ e uso de antibioticoterapia inalatória $(\mathrm{p}=0,006)$ foram maiores no HCSA enquanto idade da primeira colonização por Staphylococcus aureus $(\mathrm{p}=0,008)$, idade da mãe ( $p=0,030)$, escore clínico ( $p=0,001)$, escore socioeconômico $(\mathrm{p}=0,021)$ e uso de solução salina hipertônica $(\mathrm{p}<0,001)$ foram maiores no Hospital São Lucas.

Conclusão: os centros estudados parecem receber uma população distinta de pacientes, tanto do ponto de vista socioeconômico quanto em relação à gravidade da doença, o que interfere na escolha da terapia medicamentosa utilizada. No HCSA, serão estimuladas ações preventivas de infecção, por causa da alta incidência do complexo Burkholderia cepacia, e uma investigação atenta para alterações pulmonares mais precoces.

Palavras-chave: fibrose cística, pediatria, doença crônica.

\section{RefERENCES}

1. Pinto ICS, Silva CP, Britto MCA. Perfil nutricional, clínico e socioeconômico de pacientes com fibrose cística atendidos em um centro de referência no nordeste do Brasil. J Pneumol 2009; 35(2):137-43.
2. Bernardino AL, Ferri A, Passos-Bueno MR, Kim CEA, Nakaie CMA, Gomes $\mathrm{CET}$ et al. Molecular analysis in Brazilian cystic fibrosis patients reveals five novel mutations. Genet Test 2000; 4(1):69-74.

3. Cohen-Cymberknoh M, Shoseyov D, Kerem E. Managing cystic fibrosis: strategies that increase life expectancy and improve quality of life. Am J Respir Crit Care Med 2011; 183(11):1463-71.

4. Royal Brompton Hospital. Clinical guidelines for the care of children with cystic fibrosis. 5.ed. 2011. [citado 2011 out 10]. Available at: http://www. rbht.nhs.uk/childrencf.

5. Li Z, Kosorok MR, Farrell PM, Laxova A, West SE, Green CG et al Longitudinal development of mucoid Pseudomonas aeruginosa infection and lung disease progression in children with cystic fibrosis. JAMA 2005; 293(5):581-8

6. Ratjen FA. Cystic fibrosis: pathogenesis and future treatment strategies. Respir Care 2009; 54(5):595-602.

7. Raskin S, Pereira-Ferrari L, Reis FC, Abreu F, Maróstica P, Rosov T et al. Incidence of cystic fibrosis in five different states of Brazil as determined by screening of p.F508del, mutation at the CFTR gene in newborns and patients. J Cyst Fibros 2008; 7(1):15-22.

8. Abarno CP, Laurent MCR, Ribeiro NRR, Abreu FA. Caracterização das crianças e adolescentes com fibrose cística atendidos em um centro de referência no sul do Brasil. Rev HCPA 2011; 31(2):145-50.

9. Grupo Brasileiro de Estudos de Fibrose Cística (GBEFC). Registro Brasileiro de Fibrose Cística. 2.ed. 2010. [citado 2 dez 2012]. Available at: http://www. gbefc.org.br/gbefc/estudo_gbefc_2010.pdf.

10. De Monestrol I, Klint A, Sparén P, Hjelte L. Age at diagnosis and disease progression of cystic fibrosis in an area without newborn screening. Paediatr Perinat Epidemiol 2011; 25(3):298-305.

11. O'Malley CA. Infection control in cystic fibrosis: cohorting, cross-contamination, and the respiratory therapist. Respir Care 2009; 54(5):641-55.

12. Speert DP, Campbell ME, Henry DA, Milner R, Taha F, Gravelle A et al. Epidemiology of Pseudomonas aeruginosa in cystic fibrosis in British Columbia, Canada. Am J Respir Crit Care Med 2002; 166(7):988-93.

13. Mehta A, Bush A. Cystic fibrosis in the 21st century. Respir Res 2006; 34:1-10.

14. Sousa SA, Ramos CG, Leitão JH. Burkholderia cepacia complex: emerging multi-host pathogens equipped with a wide range of virulence factors and determinants. Int J Microbiol 2011; pii:607575.

15. ATS Committee on Proficiency Standards for Clinical Pulmonary Function Laboratories. ATS statement: guidelines for the six-minute walk test. Am J Resp Crit Care Med 2002; 166(1):111-7.

16. George PM, Banya W, Pareek N, Bilton D, Cullinan P, Hodson ME et al. Improved survival at low lung function in cystic fibrosis: cohort study from 1990 to 2007. BMJ 2011; 342.

17. Konstan MW, Wagener JS, Pasta DJ, Millar SJ, Jacobs JR, Yegin A et al. Clinical use of dornase alpha is associated with a slower rate of $\mathrm{FEV}_{1}$ decline in cystic fibrosis. Pediatr Pulmonol 2011; 46(6):545-53.

18. Máiz CL, Lamas FA, Ruiz VMM, Wagner SC, Gabilondo AG, Suárez CL. Tolerance of two inhaled hypertonic saline solutions in patients with cystic fibrosis. Med Clin (Barc) 2012; 138(2):57-9.

19. Rosenfeld M, Davis S, Brumback L, Daniel S, Rowbotham R, Johnson R et al. Inhaled hypertonic saline in infants and toddlers with cystic fibrosis: short-term tolerability, adherence, and safety. Pediatr Pulmonol 2011; 46(7):666-71.

20. Laube BL, Sharpless G, Carson KA, Mogayze PJ. Acute inhalation of hypertonic saline does not improve mucociliary clearance in all children with cystic fibrosis. BMC Pulm Med 2011; 11:45.

21. Prasad SA, Main E, Dodd ME; Association of Chartered Physiotherapists. Finding consensus on the physiotherapy management of asymptomatic infants with cystic fibrosis. Pediatr Pulmonol 2008; 43(3):236-44.

22. Furtado MCC, Lima RAG. O cotidiano da família com filhos portadores de fibrose cística: subsídios para a enfermagem pediátrica. Rev Latinoam Enferm 2003; 11(1):66-73.

23. Altman M, Vanpée M, Cnattingius S, Norman M. Risk factors for acute respiratory morbidity in moderately preterm infants. Paediatr Perinat Epidemiol. 2013;27(2):172-81

24. Dharan NJ, Sokolow LZ, Cheng P, Gargiullo P, Gershman K, Lynfield R et al. Child, household, and caregiver characteristics associated with hospitalization for influenza among children 6-59 months of age: an emerging infections program study. Pediatr Infect Dis J. 2014;33(6):e141-50.

25. Ramsey KA, Ranganathan S. Interpretation of lung function in infants and young children with cystic fibrosis. Respirology. 2014;19(6):792-9. 